\title{
NEW DISTRIBUTIONAL DATA ON BRYOPHYTES OF POLAND AND SLOVAKIA, 17
}

\author{
Piotr Górski, Pawee Pawlikowski, Grzegorz Vončina, Monika Staniaszek-Kik, \\ Barbara Fojcik, Anna Rusińska, StanisŁaw Rosadziński, Mariusz Wierzgoń, \\ SŁAWOMIR SZLAGOWSKI
}

Series "New distributional data on bryophytes of Poland (and Slovakia)" is a scientific bulletin of Bryological Section of Polish Botanical Society

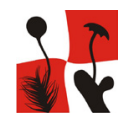

\section{Editors of the column: Piotr GóRsKi, ANNA RusińskA}

B. Fojcik, Institute of Biology, Biotechnology and Environmental Protection, Faculty of Natural Sciences, University of Silesia in Katowice, Jagiellońska 28, 40-032 Katowice, Poland, e-mail: fojcik@us.edu.pl

P. Górski, Department of Botany, Poznań University of Life Sciences, Wojska Polskiego 71 C, 60-625 Poznań, Poland, e-mail: piotr.gorski@up.poznan.pl

P. Pawlikowski, Department of Plant Ecology and Environmental Conservation, Institute of Botany, Faculty of Biology, Biological and Chemical Research Centre, University of Warsaw, Żwirki i Wigury 101, 02-096 Warsaw, Poland, e-mail: p.pawlikowski@uw.edu.pl

S. Rosadziński, e-mail: stanros@gmail.com

A. Rusińska, Natural History Collections, Adam Mickiewicz University, Umultowska 89, 61-614 Poznań, Poland, e-mail: annarus@amu.edu.pl

M. Staniaszek-Kik, Department of Geobotany and Plant Ecology, University of Łódź, Banacha 12/16, 90-237 Łódź, Poland, e-mail: kik@biol.uni.lodz.pl

S. Szlagowski, e-mail: slawomir.szlagowski@onet.eu

G. Vončina, Pieniny National Park, Jagiellońska 107 B, 34-450 Krościenko nad Dunajcem, Poland, e-mail: gvoncina@poczta.onet.pl

M. Wierzgoń, Institute of Biology, Biotechnology and Environmental Protection, Faculty of Natural Sciences, University of Silesia in Katowice, Jagiellońska 28, 40-032 Katowice, Poland,

e-mail: mariuszwierzgon@gmail.com

\begin{abstract}
This work presents a list of new localities for Acaulon muticum, Cephaloziella elachista, Cinclidium stygium, Cololejeunea calcarea, Ctenidium molluscum, Frullania dilatata, Helodium blandowii, Paludella squarrosa, Paraleucobryum longifolium, Riccardia latifrons, Scapania aequiloba, Scorpidium scorpioides, Sphagnum papillosum, S. riparium, Syntrichia laevipila, S. latifolia, S. virescens, Tortella inclinata, Trilophozia quinquedentata and Zygodon dentatus in Poland or Slovakia.
\end{abstract}

Key words: rare species, mosses, liverworts, Tatra Mts., Poland, Slovakia

1. Acaulon muticum (Schreb. ex Hedw.) Müll. Hal.

Author: M. STANIASZEK-KiK

ATMOS Dd-87: Central Poland, Central Poland Lowlands (Niziny Środkowopolskie), Southern Masovia Hills (Wzniesienia Południowomazowieckie), Piotrków Plain (Równina Piotrkowska), Łódzkie voivodeship, Tomaszów Mazowiecki county, Łaznowska Wola village, $51.667503^{\circ} \mathrm{N}, 19.703275^{\circ} \mathrm{E}$, on bare soil on stubble field; accompanying species included Tortula truncata, T. acaulon and Bryum rubens, leg., det. M. Staniaszek-Kik, 14.02.2019 (LOD).

Acaulon muticum is a very small, ephemeral moss, growing on bare soil in stubble fields, gravel pits, 
and on banks and roadsides (SMITH 2004). It is included in the red list of threatened species (category R; ŻARNOwIEC et al. 2004). Aucalon muticum is known from many sites in Poland (Wierzcholska \& PlášEK 2006, Armata \& Zubel 2007, Fojcik 2011, Stebel 2011), but their number may be higher, since the moss is small and can be easily overlooked (PORLEY 2008, Stebel 2011). So far, this species has not been reported from Łódzkie province (STANIASZEK-KIK \& WOLSKI 2009).

\section{Cephaloziella elachista (J.B. Jack ex Gottsche \& Rabenh.) Schiffn.}

Author: M. WIERZGOŃ

ATMOS Ec-59: S Poland, Woźniki-Wieluń Upland (Wyżyna Woźnicko-Wieluńska), Krzepice Depression (Obniżenie Krzepickie), Opole Province, Lachowskie-Marki village, "Nad Wyderką" ecological site, $51.0935661^{\circ} \mathrm{N}, 18.571165^{\circ} \mathrm{E}$, on the border between pine forest and polyhumus-type lake, marshy area, on peat and well decaying wood pieces, between Dicranella cerviculata shoots, occasionally with Cephalozia bicuspidata, leg. M. Wierzgoń, 5.08.2014, det. P. Górski (KTU).

Cephaloziella elachista is associated with poor fens and raised bogs. Recorded mostly in the north and at scattered sites in central Poland (SzwEYKowsKi 2006). Recently, it has often been reported from Western Pomerania (GóRsKI 2013, Górski et al. 2015a, b, GóRSKI et al. 2016b, GórsKi \& KIASZEWICZ 2018, GóRSKI et al. 2018), as well from Lubuskie Lakeland (GóRSKI et al. 2015a). In the south this species is rarely noted, and is known from the Bystrzyckie Mts. (e.g. KoŁA 1967, GóRsKI et al. 2016a). The present record of Cephaloziella elachista is the first report from the Woźniki-Wieluń Upland, and makes it a new species of liverwort flora of Opole province.

\section{Cinclidium stygium Sw.}

Author: P. PAWLIKOWSKI

ATMOS Af-98: NE Poland, Lithuanian Lake District (Pojezierze Litewskie), Eastern Suwałki Lakeland (Pojezierze Wschodniosuwalskie), Suwałki Landscape Park, Podlasie Province, Suwałki county, Rutka-Tartak commune, small soligenous rich fen constituting a still thriving remnant of a former more extensive soligenous system E of the Okragłe Lake in the Szeszupa river valley, S of the village of Kleszczówek, $54.2672^{\circ} \mathrm{N}, 22.8965^{\circ} \mathrm{E}$, species-rich brown moss-small sedge vegetation with Hamatocaulis vernicosus, Limprichtia cossonii, Calliergonella cuspidata, Tomentypnum nitens, Carex rostrata and Menyanthes trifoliata; the species grows quite abundantly, often along with Helodium blandowii (covering ca a dozen of $\mathrm{m}^{2}$ ), leg., det. P. Pawlikowski, 23.08.2017 (WA), not. P. Pawlikowski, 10.07.2018.
Cinclidium stygium is a rich fen specialist and a relic species in the temperate zone (Dierssen 2001, PaWLiKowski 2006), considered endangered in Poland (category E, ŻARNOwIEC et al. 2004). It has been reported from numerous localities in the lakelands of northern Poland and scattered, isolated sites elsewhere (SZAFRAN 1961). In north-eastern Poland, the species is locally still thriving and sometimes even abundant in the Augustów Plain and Sejny Lakeland (e.g. PaWlikowski 2010, Sокоєоwsкi 2010, WiERZCHOLSKA et al. 2010), but is increasingly rare in Warmia and Masuria province, recently reported only from the eastern part of the region (e.g. ŁACHACZ \& Olesiński 2000, Bloch-Orfowska \& Pisarek 2005). In the Suwałki Landscape Park, C. stygium was reported from four localities (the Czarna Hańcza river valley $\mathrm{N}$ of the settlement of Turtul, a mire adjacent to the $\mathrm{N}$ part of the Kopane Lake, a mire adjacent to Lake Linówek, and a mire adjacent to Lake Postawelek) by KaWECKA \& KaRCZMARZ (1993), but none of them has been confirmed despite dedicated surveys (P. Pawlikowski unpublished data from the years 2002-2019).

\section{Cololejeunea calcarea (Lib.) Schiffn.}

Author: G. VončInA

ATMOS Ge-31: S Poland, Spiskie Klippen (Skalice Spiskie), Małopolska Province, Nowy Targ county, Krempachy village, Przełom Białki in Krempachy nature reserve, $49.42903^{\circ} \mathrm{N}, 20.13306^{\circ} \mathrm{E}$, on the shady limestone rock called Kramnica in the Norway spruce forest, alt. $630 \mathrm{~m}$ above sea level (a.s.l.), leg., det. G. Vončina, 16.06.2018 (SOSN).

Cololejeunea calcarea is a rare liverwort in Poland, restricted to limestone mountains, mainly to Pieniny, the Tatras, a few in the Sudetes and around Kraków (SZWEYKOWSKI \& KoźLICKA 1974). The most recent record from the Polish and Slovak Tatras concerns a number of localities (GóRSKI \& VÁŇA 2014, GóRSKI et al. 2016b). The species is associated especially with the shaded, calcareous rocks where it grows alongside other mosses like Neckera crispa, Anomodon spp. or liverworts like Pedinophyllum interruptum, Lejeunea cavifolia. The described site is the westernmost locality in the Skalice Spiskie Klippen, while the second site is situated in an extreme position on the east on the Zielone Skałki rocks near Falsztyn village (ОснYRA \& CYKOWSKa 2008). In the neighbouring range of the Pieniny Mts. the species has been noted more frequently (SzWEYKowsKi \& KoźLICKA 1974).

\section{Ctenidium molluscum (Hedw.) Mitt.}

Author: B. FOJCIK

ATMOS Fc-69: S Poland, Silesian Upland (Wyżyna Śląska), Rybnik Plateau (Płaskowyż Rybnicki), Marklowice, sanctuary Studzienka Jankowicka, $50.0530^{\circ} \mathrm{N}$, 
$18.5358^{\circ} \mathrm{E}$, on concrete-slag wall of the chapel in mixed forest, leg., det. B. Fojcik, 7.03.2019 (KTU).

Ctenidium molluscum is a multizonal mountain species (Stebel 2006), rarely recorded in the lowlands (Ochyra et al. 1985). In the southern uplands of Poland this calcicole moss occurs mainly in rocky areas (Kuc 1964). Due to geological conditions, the species has not been noted so far in the Rybnik Plateau or in neighbouring regions (STEBel 1997b). The described site is of an anthropogenic nature.

\section{Frullania dilatata (L.) Dumort.}

\section{Author: M. WIERZGoŃ}

ATMOS Fd-53: S Poland, Silesian Upland, Jaworzno Hills (Pagóry Jaworznickie), Silesia Province, Katowice city, Murcki Forest (Las Murckowski), $50.155250^{\circ} \mathrm{N}, 19.057133^{\circ} \mathrm{E}$, in mixed forest, on the upper branches of recently fallen Quercus robur, small patch (less than $3 \mathrm{~cm}^{2}$ ), leg., det. M. Wierzgoń, 7.11.2017 (KTU).

Frullania dilatata is an epiphytic species which occurs throughout Poland (GóRSKI \& ROMAŃSKI 2018). It usually grows on the bark of deciduous trees, and occasionally on stones. It is widespread and locally common in the Beskidy Zachodnie Mts. (Stebel \& ZubeL 2018), and quite frequent in the Silesian Foothills (GórsKi et al. 2016a, Stebel \& Zubel 2018). Moreover, it was reported from the Pszczyna Plain (Stebel 1992), the Racibórz Gate, and the Racibórz Basin (Stebel 1997a). Two sites were noted from the Silesian Upland, in Chełm, in the nature reserve "Kamień Śląski" (Stebel 1997a), and the Katowice Upland in the Dąbrowa Forest near Gliwice (STEBel 2000). Therefore, it is the third site of Frullania dilatata in the Silesian Upland and the first record within Katowice city.

\section{Helodium blandowii (F. Weber \& D. Mohr) Warnst.}

\section{Author: P. PAwLIKowsKi}

ATMOS Af-98: NE Poland, Lithuanian Lake District, Eastern Suwałki Lakeland, Suwałki Landscape Park, Podlasie Province, Suwałki county, Rutka-Tartak commune, soligenous rich fen in a deep valley south of the Kojle Lake, $54.2683^{\circ} \mathrm{N}, 22.8867^{\circ} \mathrm{E}$, species-rich brown moss-small sedge vegetation with Hamatocaulis vernicosus, Calliergonella cuspidata, Marchantia aquatica, Tomentypnum nitens, Carex diandra, C. lasiocarpa, Menyanthes trifoliata; the species forms ca a dozen small clumps (covering a few $\mathrm{m}^{2}$ ), not. P. Pawlikowski, 23.08.2017.

Helodium blandowii is considered endangered in Poland (E category, ŻARNowIEC et al. 2004). The species is restricted to fens, often moderately covered with shrubs and trees, especially in the post-glacial landscape of N and NW Poland (ОснYra et al. 1988b). According to OchYRA et al. (1988b), H. blandowii is particularly typical for oligotrophic, acidifying fens, but other authors have shown that it has a much broader ecological niche, being outstandingly tolerant towards acidic conditions (in comparison with other mire specialists among brown-mosses) but also occurring in alkaline sites (HedenÄs 2003, PAwLIKOWSKI 2006). In the Lithuanian Lake District where the newly discovered locality is situated $\mathrm{H}$. blandowii is still quite widespread and sometimes abundant (e.g. Pawlikowski et al. 2009, Wierzcholska et al. 2010, WoŁejкo et al. 2012), but in the Suwałki Landscape Park it has been recorded from two localities so far (Kawecka \& Karczmarz 1993, Pawlikowski 2008); both have recently been confirmed (P. Pawlikowski unpublished data, 2011, 2019).

\section{Paludella squarrosa (Hedw.) Brid.}

Author: P. PAwLIKowsKi

ATMOS Af-98: NE Poland, Lithuanian Lake District, Eastern Suwałki Lakeland, Suwałki Landscape Park, Podlasie Province, Suwałki county, Rutka-Tartak commune, small soligenous rich fen constituting a still thriving remnant of a former more extensive soligenous system E of the Okrągłe Lake in the Szeszupa river valley, $\mathrm{S}$ of the village of Kleszczówek, $54.2674^{\circ} \mathrm{N}, 22.8965^{\circ} \mathrm{E}$, species-rich brown mosssmall sedge vegetation with Hamatocaulis vernicosus, Limprichtia cossonii, Calliergonella cuspidata, Campylium stellatum, Tomentypnum nitens, Carex rostrata and Menyanthes trifoliata; scarce specimens in $T$. nitens clumps, not. P. Pawlikowski, 10.07.2018.

Paludella squarrosa is a relic species and a rich fen specialist (Ochyra et al. 1988a) considered endangered in Poland (category E, ŻARNOWIEC et al. 2004). It is known mainly from the post-glacial lakelands of north and north-western Poland, but also from upland areas of southern Poland (including the region of Polesie), with scarce, isolated localities reported elsewhere, including the mountains (Ochyra et al. 1988a). In north-eastern Poland, the species is locally still thriving, and in the Lithuanian and Masurian Lake Districts very locally even abundant (e.g. PAwLIKOWSKI 2010, SOKO£OWSKI 2010, WIERZCHOLSKA et al. 2010, P. Pawlikowski unpubl. 2009-2018). In the Suwałki Landscape Park, P. squarrosa has been reported only from a spring fen in a deep valley south of Lake Kojle (KawecKa \& Karczmarz 1993) and the presence of the species there has recently been confirmed, leg., det. P. Pawlikowski, 23.08.2017 (WA).

\section{Paraleucobryum longifolium (Ehrh. ex Hedw.) Loeske}

Author: B. FoJCIK

ATMOS Fc-59: S Poland, Silesian Upland, Rybnik Plateau, city of Rybnik, Wielopole district, $50.1201^{\circ} \mathrm{N}$, $18.5599^{\circ} \mathrm{E}$, on the bark of Quercus robur in mixed 
forest, near a small mid-forest river (tributary of the Ruda river), leg., det. B. Fojcik, 17.03.2019 (KTU).

Paraleucobryum longifolium is a multizonal mountain species (STEBel 2006), very rarely recorded in the southern uplands of Poland (Kuc 1964). In the lowlands it is also rare, but locally it is observed more frequently in the northern lake districts (SZAFRAN 1957), e.g. in the Kartuzy Lake District (RusiŃsKA 1981). This calcifuge moss grows mainly on bedrock. However, in the described site it grew as an epiphyte. The species has not been noted so far in the Rybnik Plateau or in most neighbouring regions (STEBEL 1997b).

\section{Riccardia latifrons (Lindb.) Lindb.}

\section{Author: M. WiERZgOŃ}

ATMOS Fd-53: S Poland, Silesian Upland, Jaworzno Hills, Silesia Province, Katowice city, Murcki Forest (Las Murckowski), $50.160700^{\circ} \mathrm{N}, 19.073400^{\circ} \mathrm{E}$, mixed coniferous forest, on the well decaying pine log, created loose patches (more than $20 \mathrm{~cm}^{2}$ ) with Cephalozia bicuspidata, leg., det. M. Wierzgoń, 18.10.2017, conf. P. Górski (KTU).

Riccardia latifrons is an epixylic liverwort recorded mainly on dead wood and occasionally on exposed peat, growing in shady, moist forests and swamps. It occurs throughout Poland (SzWEYKOwSKI \& KoźLICKA 1980), more often in the lowlands, with a less frequent record in mountain ranges (GóRSKI 2013). The species in Silesian province is very rare and vulnerable (VU category, Stebel 2011, Stebel et al. 2012), which is related to intensive forest management (small amount of dead wood, drainage of land). In Silesian province, Riccardia latifrons has been noted only in a few sites from the Beskid Śląski Mts. (RejMENT-GroCHOWsKA 1950), the Beskid Żywiecko-Orawski Mts. (Klama 1996, Górski et al. 2017), the Pszczyna Plain, Pagóry Jaworznickie (Stebel \& SMOLiŃSKa 2013) and the Liswarta Depression (Stebel 2011). The present record is the second from the Silesian Upland.

\section{Scapania aequiloba (Schwaegr.) Dumort.}

\section{Author: P. GóRskI}

Poland: ATMOS Ge-50, High Tatra Mts (Tatry Wysokie), MGRS 34UDV3155, upper part of Waksmundzki Żleb gully, $49.25120^{\circ} \mathrm{N}, 20.05832^{\circ} \mathrm{E}, 49.25066^{\circ} \mathrm{N}$, $20.05768^{\circ} \mathrm{E}$, alt. $1610,1655 \mathrm{~m}$ a.s.l., leg., det. P. Górski, 30.07.2016 (POZNB 2075, 2076, 2077, 2320); MGRS 34UDV3256, spruce forest east to the Rówień Waksmundzka, $49.25539^{\circ} \mathrm{N}, 20.07082^{\circ} \mathrm{E}$, alt. $1365 \mathrm{~m}$ a.s.l., calcareous boulder, leg., det. P. Górski, 27.07.2016 (POZNB 2170); ATMOS Gd-58, S Poland, Western Tatra Mts: MGRS 34UDV1150, upper part of Wyżnia Jarząbcza dolina valley, N from Niska Przełęcz pass, $49.20042^{\circ} \mathrm{N}, 19.78706^{\circ} \mathrm{E}$, alt. $1739 \mathrm{~m}$ a.s.l., rocky outcrops, leg., det. P. Górski, 14.07.2017 (POZNB 2644); MGRS 34UDV1456, at the mouth of Dolina
Dudowa valley, $49.25306^{\circ} \mathrm{N}, 19.81867^{\circ} \mathrm{E}$, alt. $1025 \mathrm{~m}$ a.s.1., leg., det. P. Górski, 11.07.2017 (POZNB 2643); ATMOS Gd-59, S Poland, Western Tatra Mts: MGRS 34UDV2054, Dolina Mułowa valley, bottom plateau of the kettle, $49.23403^{\circ} \mathrm{N}, 19.90496^{\circ} \mathrm{E}$, alt. $1820 \mathrm{~m}$ a.s.l., leg., det. P. Górski, 22.09.2015 (POZNB 2645).

SLOVAKIA, Belianske Tatra Mts (Tatry Bielskie): MGRS 34UDV3954, near Štefanka stream, $49.24322^{\circ} \mathrm{N}, 20.16857^{\circ} \mathrm{E}, 49.24338^{\circ} \mathrm{N}, 20.16813^{\circ} \mathrm{E}$, alt. 1257, $1270 \mathrm{~m}$ a.s.l., calcareous outcrops in thickets of Sorbus aucuparia above the stream, leg., det. P. Górski, 1.09.2018 (POZNB 2636, 2640); MGRS 34UDV3957, Medzistenná dolina valley, near Międzyścienna Przełęcz pass, $49.26745^{\circ} \mathrm{N}$, $20.17086^{\circ} \mathrm{E}$, alt. $1175 \mathrm{~m}$ a.s.l., leg., det. P. Górski, 28.07.2016 (POZNB 2329); MGRS 34UDV4054, Mt Štefan, $49.24133^{\circ} \mathrm{N}, 20.18169^{\circ} \mathrm{E}$, alt. $1530 \mathrm{~m}$ a.s.l., leg., det. P. Górski, 1.09.2018 (POZNB 2642); MGRS 34UDV4156, N slope of Mt Havran (above Stará Polana glade), $49.25790^{\circ} \mathrm{N}, 20.20114^{\circ} \mathrm{E}$, alt. $1465 \mathrm{~m}$ a.s.l., leg., det. P. Górski, 28.08.2018 (POZNB 2638); MGRS 34UDV4755, Babia dolina valley (upper part of Babilovská dolina valley), $49.24766^{\circ} \mathrm{N}, 20.27452^{\circ} \mathrm{E}$, alt. $970 \mathrm{~m}$ a.s.l., leg., det. P. Górski, 28.07.2016 (POZNB 2194); SlovaKIA, High Tatra Mts: MGRS 34UDV2545, Niedźwiedzia Perć path, below Mt Nižná priehyba, $49.15895^{\circ} \mathrm{N}, 19.97938^{\circ} \mathrm{E}$, alt. $1595 \mathrm{~m}$ a.s.l., rocky ledge near unmarked path, leg., det. P. Górski, 7.09.2016 (POZNB 2212); MGRS 34UDV2546, lower part of Kotlina (Krywańskie Koryto), rocky walls in SW part of the valley, $49.16867^{\circ} \mathrm{N}, 19.98477^{\circ} \mathrm{E}$, alt. $1562 \mathrm{~m}$ a.s.l., leg., det. P. Górski, 10.08.2015 (POZNB $2425,+2)$; MGRS 34UDV3452, lower part of Spismichalova dolina valley, $49.22111^{\circ} \mathrm{N}, 20.10626^{\circ} \mathrm{E}$, alt. $1260 \mathrm{~m}$ a.s.l., calcareous boulder in spruce forest, leg., det. P. Górski, 1.08.2015 (POZNB 2637, +3); MGRS 34UDV3551: upper part of Spismichalova dolina valley, calcareous outcrops, $49.21374^{\circ} \mathrm{N}, 20.12080^{\circ} \mathrm{E}$, alt. $1854 \mathrm{~m}$ a.s.1., leg., det. P. Górski, 30.08.2015 (POZNB 2639, +3); upper part of Spismichalova dolina valley, calcareous outcrops near unmarked path, $49.21629^{\circ} \mathrm{N}, 20.12113^{\circ} \mathrm{E}$, alt. $1482 \mathrm{~m}$ a.s.l., leg., det. P. Górski, 1.08.2015 (POZNB 2641, +3); MGRS 34UDV3752: High Tatra Mts., Skupina Širokej, upper part of the Svištovská dolina valley, calcareous humus, rock crevices, $49.22257^{\circ} \mathrm{N}, 20.14188^{\circ} \mathrm{E}$, alt. $1620 \mathrm{~m}$ a.s.l., $49.22081^{\circ} \mathrm{N}, 20.14201^{\circ} \mathrm{E}$, alt. $1628 \mathrm{~m}$ a.s.l., $49.22243^{\circ} \mathrm{N}, 20.14125^{\circ} \mathrm{E}$, alt. $1610 \mathrm{~m}$ a.s.l, leg., det. P. Górski, 8.11.2015, 11.11.2015 (POZNB 1997, 2002, 2646); SLOVAKIA, Western Tatra Mts (Tatry Zachodnie), Široký žlab gully (NE from Mt Osobitá), $49.26642^{\circ} \mathrm{N}, 19.73153^{\circ} \mathrm{E}$, alt. $1135 \mathrm{~m}$ a.s.l., not. P. Górski, 24.09.2015.

Scapania aequiloba is a relatively common species in the Tatra Mts. and grows on humus formed from limestone, and less often on dead wood. It is a mountainwide species distributed quite evenly in all the mountain belts. It has been found at altitudes 
between 800 m a.s.l. (Western Tatra Mts, Račkova dolina valley; ŠMARDA 1937, DUDA \& VÁŇA 1970; Belianske Tatra Mts, Tatranská Kotlina, DudA \& VÁŇA 1970) and $2300 \mathrm{~m}$ a.s.l. (High Tatra Mts, Zlomiskova štrbina; ŠMARDA 1961). Of all eight calciphilous species of the genus Scapania, it has usually been documented from sites in the Polish part of the Western Tatra and Belianskie Tatra Mts (GóRSKI \& VÁŇA 2014, 2015). Recently, information on 123 new sites of this plant from the Tatra Mts was published (GóRSKI \& VÁŇA 2015). These data update the distribution map of $S$. aequiloba mainly for areas where relatively few sites of this plant were recorded, i.e. Slovak parts of the High Tatra and Slovak Western Tatra Mountains. Outside the Tatra Mts., S. aequiloba is known from the Sudety Mts. (Góry Stołowe Mts, Szweykowski 1953), Pieniny Mts. (Szafran 1952, SzweYKowski 1961), Babia Góra Massive (Klama 2004, 2013), Gorce Mts. (MierzeŃSKA 1994), Beskid Żywiecko-Orawski (KLAMA 1996), Skalice Nowotarskie and Spiskie Klippen (OchYRA \& CүкоwsKa 2008), Ojcowski National Park (PatKOWA 1961), Beskid Sądecki (Mamczarz 1977) and Bieszczady Mts. (Szweykowski \& Buczkowska 1996).

\section{Scorpidium scorpioides (Hedw.) Limpr.}

Author: P. PAwlikowsKi

ATMOS Af-98: NE Poland, Lithuanian Lake District, Eastern Suwałki Lakeland, Podlasie Province, Suwałki county, Jeleniewo commune, mire $S$ of the Szurpity Lake, between the lake and Góra Opartowo hill, $54.0547^{\circ} \mathrm{N}, 22.6745^{\circ} \mathrm{E}$, strongly inundated rich fen vegetation patches with Hamatocaulis vernicosus, Menyanthes trifoliata, Carex lasiocarpa, C. rostrata, C. chordorrhiza and Utricularia minor, forming small carpets covering ca a dozen $\mathrm{m}^{2}$, leg., det. P. Pawlikowski 18.07.2011 (WA); ATMOS Af-98: NE Poland, Lithuanian Lake District, Eastern Suwałki Lakeland, Suwałki Landscape Park, Podlasie Province, Suwałki county, Rutka-Tartak commune, small soligenous rich fen constituting a still thriving remnant of a former more extensive soligenous system E of the Okragge Lake in the Szeszupa river valley, S of the village of Kleszczówek, $54.2252^{\circ} \mathrm{N}, 22.8966^{\circ} \mathrm{E}$, species-rich brown moss-small sedge vegetation in shallow depressions with Limprichtia cossonii, Cinclidium stygium, Carex lasiocapa, C. limosa and Comarum palustre, forming carpets covering several dozens of square meters, leg., det. P. Pawlikowski, 23.08.2017 (WA), not. P. Pawlikowski, 10.07.2018; mire vegetation there and numerous rare species are threatened because of desiccation and expansion of shrubs due to functioning drainage ditches nearby.

Scorpidium scorpioides is a rich fen specialist (OcHYRA et al. 1988c) considered endangered in Poland (category E, ŻARNOwIEC et al. 2004). It has been recorded throughout the country, but mostly in post-glacial landscapes of northern Poland and in the region of Polesie in eastern Poland (Ochyra et al. 1988c). In north-eastern Poland the species is still present, but while it is contemporarily very rare in Warmia and Masuria province (as summarized by PawlikowsKi 2017), in the Biebrza river valley in Biebrza National Park (P. Pawlikowski unpublished data from the year 2003, Ł. Krajewski, K. Topolska unpublished data from the years 2016-2017, WoŁejKo et al. 2012) and in the northernmost part of Masovia province (JarzombKowski \& Kozub 2011) it is still thriving and sometimes even abundant in the Lithuanian Lake District, but only in the regions of the Eastern Suwałki Lakeland and Augustów Plain (e.g. Tyszkowski 1993, Jutrzenka-Trzebiatowski \& SzarejKo 2001, Pawlikowski et al. 2009, Pawlikowski 2010, Wierzcholska et al. 2010, WolejKo et al. 2012, KraJEWSKI et al. 2015). In the Suwałki Landscape Park, the species was reported from eight localities (KAWECKA \& KARCZMARZ 1993). Despite numerous surveys, only two of them have recently been confirmed (a mire $\mathrm{E}$ of the Boczniel Lake and a mire adjacent to Lake Linówek), while four populations have certainly vanished, and two others have not been confirmed so far but need further research (P. Pawlikowski unpublished data, 2002-2019).

\section{Sphagnum papillosum Lindb.}

Author: G. VončinA

ATMOS Ge-50: S Poland, High Tatra Mts, Małopolska Province, Zakopane (Tatrzański) county, Poronin commune, Tatra National Park, $49.26317^{\circ} \mathrm{N}$, $20.05658^{\circ} \mathrm{E}$, Wyżnia Pańszczycka Młaka peat bog, alt. $1350 \mathrm{~m}$ a.s.l., leg., det. G. Vončina, 7.08.2016 (SOSN).

Sphagnum papillosum occurs throughout Poland with varying frequency. On the Polish lowland it is sometimes quite frequent (Stebel 2017). The presented locality is the second in the Polish Tatra Mts. The first site was reported from Mt Świstówka Roztocka at $1500 \mathrm{~m}$ a.s.l., which is also the highest locality of this moss in Poland (Melosik 2006, Stebel 2017). Beyond the Tatra Mts. the nearest site of this moss was noted in the Kotlina Orawsko-Nowotarska basin (Lisowski 1961, Ochyra 1978, KoczUr 2015) and the Orawsko-Jordanowskie Foothills on Polish stations (STEBel \& VonČINA 2014).

In the Tatra Mts., Sphagnum papillosum forms compact hummocks between Sphagnum magellanicum, S. fallax, and S. cuspidatum. The peat bog is surrounded by spruce forest and is located near a touristic path. This moss occurs on oligotrophic or mesotrophic peat bogs with Sphagnum majus, S. magellanicum, S. flexuosum or S. fallax (LAINE et al. 2011). Under Polish law this species has the status of a partly protected plant (ROZPORZĄDZENIE... 2014), although in the years 2004-2014 it was a strictly protected plant. In the Polish red list S. papillosum has category I (ŻARNOWIEC et al. 2004). 


\section{Sphagnum riparium Ångstr.}

Author: B. FoJcIK

ATMOS Fd-60: S Poland, Silesian Upland, Rybnik Plateau, city of Rybnik, Boguszowice district, $50.0396^{\circ} \mathrm{N}$, $18.5947^{\circ} \mathrm{E}$, spring area in the bushes at the edge of the forest, leg., det. B. Fojcik, 20.10.2017 (KTU).

Sphagnum riparium is classified as boreal species (DülL 1984). In Poland, it occurs mainly in the lowlands, with few sites in the southern uplands and mountains (Kuc 1964, Stebel 2006). The species has not been noted so far in the Rybnik Plateau and in neighboring regions (STEBEL 1997b).

\section{Syntrichia laevipila Brid.}

\section{Authors: A. RusińsKA, S. RosAdZIŃSKI}

ATMOS Cb-45: Wielkopolska Region, Kotlina Gorzowska Basin (Kotlina Gorzowska), Wieleń commune, Zielonowo, near road to Jędrzejewo, $52.91305^{\circ} \mathrm{N}, 16.33769^{\circ} \mathrm{E}$, bark of an old ash Fraxinus excelsior growing on the shoulder of the field road, population area ca $5 \mathrm{~cm}^{2}$, c. spor., leg., det. S. Rosadziński 53, 11.05.2017 (POZG); ATMOS Cc-56: Wielkopolska Region, Pojezierze Poznańskie Lakeland (Pojezierze Poznańskie), Barcin commune, between Bielawy and Piechcin, $52.82777^{\circ} \mathrm{N}, 18.01027^{\circ} \mathrm{E}$, bark of the old poplar Populus $\mathrm{x}$ canadensis, growing on roadside, population area ca $3 \mathrm{~cm}^{2}$, c. spor., leg., det. A. Rusińska 9808, 16.05.2017 (POZG).

Syntrichia laevipila is very rare epiphytic moss, partly protected in Poland (RozPoRZĄDZENIE... 2014) and included in the Red list (I category, ŻARNOWIEC et al. 2004). It has some scattered, mostly historical localities across the country. Contemporarily it has been recorded from the Wielkopolska Region in Poznań (RusińsKa 2014). This photophilous species is found mainly on the bark of deciduous trees, growing on roadsides, and often forms sporophytes. It forms small cushions, sometimes together with other species from the genus Syntrichia, such as S. virescens and $S$. ruralis. It differs from them, however, in some characteristic features of leaves - both morphological (long, smooth hyaline point) and anatomical (several rows of stereid cells in cross section).

\section{Syntrichia latifolia (Bruch ex Hartm.) Hübener}

\section{Author: M. WIERZgoń}

ATMOS Fd-52: S Poland, Silesian Upland, Katowice Upland (Wyżyna Katowicka), Mikołów city, Park Planty, $50.164889^{\circ} \mathrm{N}, 18.896944^{\circ} \mathrm{E}$, on the border of urban park, on asphalt footpath, under the canopy of trees (enshadowed place), with gemmae, leg., det. M. Wierzgoń, 12.07.2019 (KTU).

Syntrichia latifolia is an uncommon epiphytic moss species which grows on the bark of deciduous trees and tends to spread on rock-like anthropogenic habitats. It occurs throughout Poland with a concentration of sites in the west and south-west parts of the country. In the Beskidy Zachodnie it was reported from the Beskid Śląski Mts. (Plášek \& Stebel 2002, Stebel 2009) and the Kotlina Żywiecka Basin (SteBEL 2008, 2009). Furthermore, it was locally reported from the Silesian Foothills (Stebel 1999, 2009), the Upper Vistula Valley, the Rybnik Plateau (Stebel 2011) and the Kraków-Częstochowa Upland (FoJcIK 2011). In the Katowice Upland it was noted twice in the city of Katowice on the bark of trees (STEBel \& Fojciк 2016). The presented record is the third site of Syntrichia latifolia in the Katowice Upland.

\section{Syntrichia virescens (De Not.) Ochyra}

Author: M. STANIASZEK-KIK

ATMOS Dd-97: Central Poland, Central Poland Lowlands (Niziny Środkowopolskie), Southern Masovia Hills, Piotrków Plain, Łódzkie voivodeship, Piotrków Trybunalski county, Czarnocin village, $51.592395^{\circ} \mathrm{N}$, $19.688432^{\circ} \mathrm{E}$, trunk of Acer pseudoplatanus and Tilia cordata in a small, old park around the school, leg., det. M. Staniaszek-Kik, 23.04.2017 (LOD); ATMOS Ed-24: Central Poland, Central Poland Lowlands, Southern Wielkopolska Lowland (Nizina Południowowielkopolska), Szczerców Basin (Kotlina Szczercowska), Łódź voivodeship, Kluki county, Słupia village, $51.302275^{\circ} \mathrm{N}, 19.284532^{\circ} \mathrm{E}$, trunk of Acer platanoides by the road, leg., det. M. Staniaszek-Kik, 12.10.2018 (LOD).

Syntrichia virescens usually grows on the bark of deciduous trees, and much less often on old walls and rocks. It is a photophilous species, which is why it usually grows on solitary roadside trees (SмITH 2004). It is found both in the open rural landscape, and as an epiphyte in urban areas (GórsKI et al. 2018, FudALI 2019). In Łódzkie province $S$. virescens has been reported from very few sites (CHMIELEWSKI \& URBANEK 1960, SANDERSKa et al. 2003, StANiAszeK-KiK 2017).

\section{Tortella inclinata (R. Hedw.) Limpr.}

Author: B. FoJcIK

ATMOS Fc-59: S Poland, Silesian Upland, Rybnik Plateau, city of Rybnik, Wielopole district, $50.1248^{\circ} \mathrm{N}$, $18.5759^{\circ} \mathrm{E}$, the roadside of a dirt road covered with gravel in mixed forest, leg., det. B. Fojcik, 17.03.2019 (KTU).

Tortella inclinata is a montane (submontane) species (Stebel 2006), rarely recorded in the southern uplands of Poland (KuC 1964) and very rarely found in the lowlands (Szafran 1957). It is a calcicole moss and usually grows on shallow rock soils (Kuc 1964). Due to geological conditions, the species has not been noted so far in the Rybnik Plateau or in neighbouring regions (STEBEL 1997b). The described site is of an anthropogenic nature. 
19. Trilophozia quinquedentata (Huds.) Bakalin [= Tritomaria quinquedentata (Huds.) Buch.]

\section{Authors: P. GóRSKI, S. SzLAGOWSKI}

SlovaKIA: MGRS 34UDV3948, High Tatra Mts, Mt Javorový štít, alt. $2418 \mathrm{~m}$ a.s.l., leg. S. Szlagowski, 15.08.2019, det. P. Górski (POZNB 2690).

One currently reported site of Trilophozia quinquedentata is located in the subnival belt, on Mt Javorový štít, which is part of the main ridge of the High Tatra Mts. This liverwort species is common in the Tatra Mts. and was reported from over 320 sites (GóRSKI \& VÁŇA 2014). Interestingly, at altitudes over 2400 $\mathrm{m}$ a.s.l. it has been recorded on only eight sites: $\mathrm{Mt}$ Lomnický štít (2633 m a.s.l., SzYSZYŁOWICZ 1885, Šoltés 1990), Mt Czarny Mięguszowiecki Szczyt (2409 m a.s.l., Cүкошsка 2008), Mt Mięguszowiecki Szczyt Wielki (2438 m a.s.l., Сүкошsка 2008), Mt Rysy and Niżne Rysy (2430-2499 m a.s.l., CYкOwsKA 2008), Sedielko nad Kotlom pass (2405 m a.s.l., GóRSKI \& VÁŇA 2014), and Mt Gerlachovský štít (2655 m a.s.l., GóRSKI \& VÁŇA 2014).

\section{Zygodon dentatus (Limpr.) Karttunen}

Author: G. VončinA

ATMOS Ge-31: S Poland, Spiskie Klippen, Małopolska Province, Nowy Targ county, Nowy Targ commune, Nowa Biała village, Przełom Białki in Krempachy nature reserve, $49.43133^{\circ} \mathrm{N}, 20.13086^{\circ} \mathrm{E}$, on the bark of living willow Salix eleagnos in the alluvial forest with willows ald poplars along the left riverbank of Białka river, alt. $625 \mathrm{~m}$ a.s.l., leg., det. G. Vončina, 16.06.2018 (SOSN).

Zygodon dentatus is a rare moss in Poland whose localities were noted in the southern part of the country, especially in the Carpathian Mountains. The species was observed on the bark of willow, which is one of the rarer phanerophytes for it. Nevertheless, the specimens were noted in a wooded area and at an altitude characteristic of its ecology (STEBEL \& ŻARNOwIEC 2017). Zygodon dentatus is a threatened moss species in Poland (E category) in the Polish Carpathians and throughout Poland (ŻRNOWIEC et al. 2004). The described sites represent the first record from the Pieniny Klippen Belt within Polish frontiers.

\section{ACKNOWLEDGEMENTS}

The contribution by Piotr Górski was supported by the Ministry of Science and Higher Education, Warsaw, Poland (statuory funds No 506.641.09.00).

\section{REFERENCES}

Armata L., Zubel R. (2007): Bryophyte flora of the

"Góry Pieprzowe" Nature Reserve on Wyżyna
Sandomierska, SE Poland. Annales Universitatis Mariae Curie-Sklodowska, Sectio C, Biologia 62: $17-26$.

Bloch-OrŁowska J., Pisarek W. (2005): Rzadkie i zagrożone rośliny naczyniowe oraz mchy torfowiska „Zocie” na Pojezierzu Ełckim. Chrońmy Przyrodę Ojczystą 61(3): 5-12.

Chmielewski T., Urbanek H. (1960): Mchy okolic Łodzi. Łódzkie Towarzystwo Naukowe 17(4): 1-16.

Сүкоwsка В. (2008): A contribution to the bryoflora of the subnival belt in the Polish Tatra Mountains. In: A. Stebel, R. Ochyra (eds). Bryophytes of the Polish Carpathians. Sorus, Poznań: 185-200.

Dierssen K. (2001): Distribution, ecological amplitude and phytosociological characterization of European bryophytes. Bryophytorum Bibliotheca 56: 1-289.

DudA J., VÁŇA J. (1970): Die Verbreitung der Lebermoose in der Tschechoslowakei - VI. Časopis Slezského Muzea, Series A, Opava 19: 65-93.

Düll R. (1984): Distribution of the European and Macaronesian mosses (Bryophytina). Part 1. Bryologische Beitraege 4: 1-114.

FoנcıK B. (2011): Mchy Wyżyny Krakowsko-Częstochowskiej w obliczu antropogenicznych przemian szaty roślinnej. Prace Naukowe Uniwersytetu Śląskiego w Katowicach 2800, Katowice.

FudALI E. (2019): Distribution of epiphytic bryophytes in Wroclaw in relation to urban-use complexes. Biodiversity Research and Conservation 54: 11-21.

GóRsKI P. (2013): Wątrobowce (Marchantiophyta) Leśnego Kompleksu Promocyjnego „Lasy Środkowopomorskie" (Pomorze Zachodnie). PGL Lasy Państwowe Nadleśnictwo Karnieszewice, Wydawnictwo Uniwersytetu Przyrodniczego w Poznaniu, Sianów-Poznań.

Górski P., Kapustyński T., Kozub Ł., Dembicz I., Rosadziński S., Staniaszek-Kik M., Rusińska A., SMOCZYK M. (2015a): New distributional data on bryophytes of Poland and Slovakia, 4. Steciana 19(4): 221-230.

GóRsKi P., KIASZEWICZ K. (2018): New distributional data on bryophytes of Poland, 15. Steciana 22(3): 97-100.

Górski P., Kujawa-Pawlaczyk J., Pawlaczyk P. (2018): New distributional data on bryophytes of Poland, 16. Steciana 22(4): 161-165.

GóRski P., Romański M. (2018): Wątrobowiec Frullania dilatata $\mathrm{w}$ Wigierskim Parku Narodowym na tle jego występowania w Polsce. Steciana 22(3): 101-114.

Górski P., Smoczyk M., Pawlikowski P., Vončina G., Stebel A., Paciorek T., Staniaszek-Kik M., RomańSKI M., Wiaderny A., GabKa M., WierzcholsKa S. (2015b): New distributional data on bryophytes of Poland, 2. Steciana 19(2): 55-65. 
GóRski P., Smoczyk M., Rosadziński S., Staniaszek-KIK M., Klama H., Pawlikowski P., Wilhelm M., TopolSKA K., RomańsKi M. (2016a): New distributional data on bryophytes of Poland and Slovakia, 7. Steciana 20(3): 117-127.

GÓRSKI P., VÁŇA J. (2014): A synopsis of liverworts occurring in the Tatra Mountains (Western Carpathians, Poland and Slovakia): checklist, distribution and new data. Preslia 86(4): 381-485.

Górski P., VÁŇA J. (2015): Calciphilous species of the genus Scapania in the Tatra Mountains (Western Carpathians, Poland and Slovakia): distribution and threats. Herzogia 28(1): 28-37.

Górski P., Vončina G., Fudali E., ŻoŁnierz L. (2018): New distributional data on bryophytes of Poland and Slovakia, 13. Steciana 22(1): 13-18.

Górski P., Vončina G., Smoczyk M., Klama H., Šoltés R., Wilhelm M., Rutkowska M. (2016b): New distributional data on bryophytes of Poland and Slovakia, 8. Steciana 20(4): 191-200.

Górski P., Vončina G., Smoczyk M., Klama H., Šoltés R., Wilhelm M., RutKowsKa M. (2017): New distributional data on bryophytes of Poland and Slovakia, 9. Steciana 21(1): 31-40.

Hedenäs L. (2003): The European species of the Calliergon-Scorpidium-Drepanocladus complex, including some related or similar species. Meylania 28: $1-116$.

JarzombKowski F., Kozub Ł. (2011): Stan zagrożenia i ochrony mechowisk w krajobrazie rolniczym Mazowsza. In: W. Dembek, A. Gutkowski, H. Piórkowski (eds). Współczesne narzędzia identyfikacji oraz ochrony mokradeł i muraw w krajobrazie rolniczym. Instytut Technologiczno-Przyrodniczy, Zakład Ochrony Przyrody i Krajobrazu Wiejskiego, Falenty: 85-105.

Jutrzenka-Trzebiatowski A., Szarejko T. (2001): Zespół Caricetum buxbaumii w Wigierskim Parku Narodowym. Fragmenta Floristica et Geobotanica Polonica 8: 149-171.

KaWECKA A., Karczmarz K. (1993): Występowanie rzadkich i wyróżniających mszaków w zbiorowiskach roślinnych Suwalskiego Parku Krajobrazowego i jego okolic. Parki Narodowe i Rezerwaty Przyrody 12(1): 55-68.

Klama H. (1996): Wątrobowce (Hepaticae) Beskidu Żywiecko-Orawskiego (Karpaty Zachodnie). Monographiae Botanicae 79: 1-144.

Klama H. (2004): Wątrobowce (Marchantiophyta) Babiogórskiego Parku Narodowego. In: B.W. Wołoszyn, A. Jaworski, J. Szwagrzyk (eds). Babiogórski Park Narodowy. Monografia Przyrodnicza. Komitet Ochrony Przyrody PAN, Babiogórski Park Narodowy, Kraków: 333-356.

Klama H. (2013): Materiały do flory wątrobowców masywu Babiej Góry (Karpaty Zachodnie). Fragmenta Floristica et Geobotanica Polonica 20(1): 93-108.
Koczur A. (2015): 33. Sphagnum affine Renauld \& Cardot. In: Ellis L.T., Asthana A.K., SRivastava A., Bakalin V.A., Bednarek-Ochyra H., Cano M.J., Jiménez J.A., Alonso M., Deme J., Csiky J., Dia M.G., Campisi P., Erzberger P., Garilleti R., Gorobets K.V., Gremmen N.J.M., Jimenez M.S., SuÁrez G.M., Jukonienė I., Kiebacher T., Kirmaci M., Koczur A., Kürschner H., Lara F., Mazimpaka V., Larraín J., Lebouvier M., Medina R., Natcheva R., Newsham K.K., Nobis M., NowaK A., Ören M., ÖzçeliK A.D., Orgaz J.D., Peralta D.F., Plášek V., Č́́hal L., Ristow R., SAWicki J., SchäFer-Verwimp A., Smith V.R., Stebel A., Ştefănuț S., Subkaitė M., Sun B.Y., Useliené A., Uyar G., VÁŇA J., Yoon Y.-J., PARK S.J. (2015): New national and regional bryophyte records, 43. Journal of Bryology 37(2): 140.

KoŁA W. (1967): Materiały do flory wątrobowców Gór Bystrzyckich. Acta Universitatis Wratislaviensis 62, Prace Botaniczne 8: 85-98.

Krajewski Ł., PaWlikowski P., GutowsKa E., Jarzombkowski F., Kauzal P., Kotowska K., Kowalska M. BrzeziŃSKA K., DzIERŻa P. (2015): Nowe dane o rozmieszczeniu i warunkach siedliskowych ramienic (Characeae) Polski (2010-2012) z uwzględnieniem terenów chronionych i objętych programem rolnośrodowiskowym. Woda-Środowisko-Obszary Wiejskie 15, 2(50): 65-85.

Kuc M. (1964): Briogeografia wyżyn południowych Polski. Monographiae Botanicae 17: 1-211.

Łachacz A., Olesiński L. (2000): Flora i roślinność trzęsawiskowego torfowiska Jeziorko na Pojezierzu Mazurskim. Fragmenta Floristica et Geobotanica Polonica 7: 129-144.

Laine J., Harju P., Timonen T., Laine A., Tuittila E.-S., MinkKinen K., Varsander H. (2011): The intricate beauty of Sphagnum mosses - a Finnish guide to identification. University of Helsinki, Helsinki.

Lisowski S. (1961): Bryotheca Polonica. Fasc. 49. No. 1501-1525. Musci Convalle "Kotlina Nowotarska” (Carpati Occid.). Academia Scientiarum Poloniae, Posnaniae.

MAMCZARz H. (1977): Brioflora i zbiorowiska mszaków Beskidu Sądeckiego. Cz. 1. Brioflora Beskidu Sądeckiego. Monographiae Botanicae 54: 1-158.

Melosik I. (2006): Species of the type section of Sphagnum (Bryophyta, Sphagnaceae) in Poland. Biodiversity Research and Conservation 1-2: 6976.

MierzeńSKA M. (1994): Wątrobowce Gorców. Fragmenta Floristica et Geobotanica Series Polonica 1: 235-346.

Ochyra R. (1978): Musci Poloniae Exiccati. Centuria II. Nr 101-200. Fragmenta Floristica et Geobotanica 24(3): 487-514.

Ochyra R., Cүкоwska B. (2008): The liverwort flora of the Skalice Nowotarskie and Spiskie Klippen (Polish Western Carpathians). In: A. Stebel, 
R. Ochyra (eds). Bryophytes of the Polish Carpathians. Sorus, Poznań: 143-167.

OchYra R., RusińsKa A., Szmajda P. (1985): M. 626. Ctenidium molluscum (Hedw.) Mitt. In: Z. Tobolewski, T. Wojterski (eds). Atlas of geographical distribution of spore plants in Poland. Vol. 2. Series V. Mosses (Musci). Państwowe Wydawnictwo Naukowe, Warszawa-Poznań: 29-33.

Ochyra R., Szmajda P., Bednarek H., Bocheński W. (1988a): M. 384. Paludella squarrosa (Hedw.) Brid. In: Z. Tobolewski, T. Wojterski (eds). Atlas of the geographical distribution of spore plants in Poland. Vol. 3. Series V. Mosses (Musci). W. Szafer Institute of Botany of the Polish Academy of Science, Państwowe Wydawnictwo Naukowe, Warszawa-Poznań: 5-10.

Ochyra R., Szmajda P., Bednarek H., Bocheński W. (1988b): M. 484. Helodium blandowii (Web. \& Mohr) Warnst. In: Atlas of the geographical distribution of spore plants in Poland. Vol. 3. Series V. Mosses (Musci). In: Z. Tobolewski, T. Wojterski (eds). W. Szafer Institute of Botany of the Polish Academy of Science, Państwowe Wydawnictwo Naukowe, Warszawa-Poznań: 27-33.

Ochyra R., Szmajda P., Bednarek H., Bocheński W. (1988c): M. 524. Scorpidium scorpioides (Hedw.) Limpr. In: Z. Tobolewski, T. Wojterski (eds). Atlas of the geographical distribution of spore plants in Poland. Vol. 3. Series V. Mosses (Musci). W. Szafer Institute of Botany of the Polish Academy of Science, Państwowe Wydawnictwo Naukowe, Warszawa-Poznań: 41-47.

PAŁKOwA A. (1961): Wątrobowce Ojcowskiego Parku Narodowego. Fragmenta Floristica et Geobotanica 7(1): $179-193$.

PAwLIKowsKi P. (2006): Habitat preferences and indicator value of eight threatened brown moss species in rich fens of the Lithuanian Lake District (NE Poland). Polish Journal of Environmental Studies 15(5D): 232-237.

PAWLIKOWsKI P. (2008): Nowe stanowiska zagrożonych gatunków torfowiskowych roślin naczyniowych i mchów w Suwalskim Parku Krajobrazowym i jego otulinie. Fragmenta Floristica et Geobotanica Polonica 15(1): 43-50.

PAWLIKOWsKI P. (2010): Wybrane torfowiska północno-wschodniej Polski. In: A. Obidziński (ed.). Z Mazowsza na Wileńszczyznę. Zróżnicowanie i ochrona szaty roślinnej pogranicza Europy Środkowej i Północno-Wschodniej. Polskie Towarzystwo Botaniczne, Warszawa: 327-407.

Pawlikowski P. (2017): 11. Scorpidium scorpioides (Hedw.) Limpr. In: P. Górski, A. Rusińska (eds). New distributional data on bryophytes of Poland and Slovakia, 9. Steciana 21(1): 36-37.

PaWlikowski P., JarzombKowski F., WoŁkowycki D., Kozub Ł., Zaniewski P., Bakanowska O., Banasiak Ł., Barańska K., Bielska A., Biereżnoj U., Galus M.,
Grzybowska M., Kapler A., Karpowicz J., SadowSKA I., ZARZECKI R. (2009): Rare and threatened plants of the mires in the intensively managed landscape of the Góry Sudawskie region (NE Poland). Roczniki Akademii Rolniczej w Poznaniu 388, Botanika-Steciana 13: 29-36.

Plăšek V., Stebel A. (2002): Mosses of the Čantoryjský hřbet range (Czantoria range) and its foothills (Western Carpathians - Czech Republic, Poland). Časopis Slezského Muzea, Series A, Opava 51: 1-87.

Porley R. (2008): Arable bryophytes. A field guide to the mosses, liverworts and hornworts of cultivated land in Britain and Ireland. WILDGuides. Princeton University Press, Princeton.

Rejment-Grochowska I. (1950): Czynniki ekologiczne i rozmieszczenie geograficzne wątrobowców (Hepaticae) Beskidu Sląskiego. Prace Biologiczne Śląskie 2: 3-71.

RoZPORZĄDZENIE Ministra Środowiska z dnia 9 października 2014 r. w sprawie ochrony gatunkowej roślin. (2014). Dziennik Ustaw Rzeczypospolitej Polskiej z 16 października 2014 roku, poz. 1409.

RusińsKA A. (1981): Mchy Pojezierza Kartuskiego. Prace Komisji Biologicznej Poznańskiego Towarzystwa Przyjaciół Nauk 59: 3-153.

RusiŃSKA A. (2014): 21. Syntrichia levipila Brid. In: P. Górski, A. Stebel, A. Rusińska (eds). New distributional data on bryophytes of Poland, 1 . Steciana 18(2): 82.

Sanderska A., Filipiak E., Pisarek W. (2003): Bryophytes in the Bolimów Landscape Park. Monographiae Botanicae 92: 197-231.

ŠMARDA J. (1937): Př́íspěvky k rozšîření jatrovek v Československu. Část II. Sborník Klubu přírodovědeckého v Brně 19: 39-47.

ŠMARDA J. (1961): Př́íspěvky k rozšîření jatrovek v Československu VI. Biologické práce Slovenskej Akademie Vied VII/1: 5-45.

Smith A.J.E. (2004): The moss flora of Britain and Ireland. Cambridge University Press, Cambridge.

Sокоєоwsкi A.W. (2010): Puszcza Augustowska. Centrum Informacyjne Lasów Państwowych, Warszawa.

Šoltés R. (1990): Bryotheca Tatrensis: Marchantiopsida. Zborník Prác o Tatranskom Národnom Parku 30: 277-307.

StANIASZek-KiK M. (2017): Mszaki zabytkowego cmentarza w Pławnie w województwie łódzkim (Polska środkowa). Steciana 21 (4): 185-191.

Staniaszek-KIK M., Wolski G.J.W. (2009): Mszaki zróżnicowanie, zmiany i zagrożenia. In: J.K. Kurowski (ed.). Vegetation of Central Poland. Towarzystwo Ochrony Krajobrazu, Wydawnictwo Eko-Graf, Łódź: 48-56.

Stebel A. (1992): Flora i roślinność projektowanego rezerwatu przyrody „Las Babczyna Dolina” nad rzeką Korzenicą na Równinie Pszczyńskiej Część 
2. Mszaki. Archiwum Ochrony Środowiska 3-4: 187-196.

Stebel A. (1997a): Mszaki rezerwatu przyrody „Łężczak" w Kotlinie Raciborskiej. Opolskie Towarzystwo Przyjaciół Nauk, Zeszyty Przyrodnicze 32: $11-29$.

Stebel A. (1997b): Mszaki Rybnickiego Okręgu Węglowego. Fragmenta Floristica et Geobotanica Polonica 4: 121-233.

Stebel A. (1999): Nowe stanowiska rzadkich i zagrożonych mchów w Beskidach Zachodnich i na Pogórzu Zachodniobeskidzkim (Karpaty Zachodnie). Fragmenta Floristica et Geobotanica, Series Polonica 6: 203-210.

Stebel A. (2000): Mszaki projektowanego rezerwatu przyrody „Las Dąbrowa” na Wyżynie Śląskiej. Natura Silesiae Superioris. Centrum Dziedzictwa Przyrody Górnego Śląska 4: 57-66.

Stebel A. (2006): The mosses of the Beskidy Zachodnie as a paradigm of biological and environmental changes in the flora of the Polish Western Carpathians. Medical University of Silesia, Sorus, Katowice-Poznań.

Stebel A. (2008): Mosses of the Kotlina Żywiecka Basin (Western Carpathians).In: A. Stebel, R. Ochyra (eds). Bryophytes of the Polish Carpathians. Sorus, Poznań: 11-74.

Stebel A. (2009): Mech pędzliczek szerokolistny Syntrichia latifolia (Hartm.) Huebener w Karpatach polskich i problemy jego ochrony. Chrońmy Przyrodę Ojczystą 65(4): 293-298.

Stebel A. (2011): Interesting records of bryophytes from Silesia Province (Poland). Časopis Slezského Muzea, Series A, Opava 60: 135-138.

Stebel A. (2017): Torfowce Sphagnopsida Leśnego Kompleksu Promocyjnego „Lasy Środkowopomorskie" (Pomorze Zachodnie). Nadleśnictwo Karnieszewice, Trawica.

Stebel A., Fojcik B. (2016): Changes in the epiphytic bryophyte flora in Katowice city (Poland). Cryptogamie, Bryologie 37 (4): 399-415.

Stebel A., Fojcik B., Klama H., Żarnowiec J. (2012): Czerwona lista mszaków województwa śląskiego. In: J.B. Parusel (ed.). Czerwone listy wybranych grup grzybów i roślin województwa śląskiego. Raporty Opinie 6(2): 73-104.

Stebel A., SmolińsKa D. (2013): Nowellia curvifolia (Marchantiophyta) in the "Dolina Żabnika" nature reserve (Silesia Province, Poland). Opole Scientific Society, Nature Journal 46: 28-33.

Stebel A., Vončina G. (2014): Bryophyte diversity in the flora of the Orawsko-Jordanowskie Foothills (Polish Western Carpathians). Muzeum Tatrzańskie, Zakopane.

Stebel A., Żarnowiec J. (2017): The moss genus $Z y$ godon (Orthotrichaceae) in Poland - distribution, ecological preferences and threats. Cryptogamie, Bryologie 38(3): 231-251.
Stebel A., Zubel R. (2018): Wątrobowiec Frullania dilatata (Jubulaceae) w polskiej części Karpat rozmieszczenie, ekologia, zagrożenia. Roczniki Bieszczadzkie 26: 151-168.

Szafran B. (1952): Mszaki Pienin. Ochrona Przyrody 20: 89-117.

Szafran B. (1957): Mchy (Musci). Tom 1. Flora Polska. Rośliny zarodnikowe Polski i ziem ościennych. Państwowe Wydawnictwo Naukowe, Warszawa.

Szafran B. (1961): Mchy (Musci). Tom 2. Flora Polska. Rośliny zarodnikowe Polski i ziem ościennych. Państwowe Wydawnictwo Naukowe, Warszawa.

Szweykowski J. (1953): Mszaki Gór Stołowych. Prace Komisji Biologicznej Poznańskiego Towarzystwa Przyjaciół Nauk 14(5): 1-136.

SzWEYKOWSKI J. (1961): Materiały do flory wątrobowców Pienin. Prace Komisji Biologicznej Poznańskiego Towarzystwa Przyjaciół Nauk 24(1): 1-39.

SzWEYKOWSKI J. (2006): An annotated checklist of Polish liverworts and hornworts. - Krytyczna lista wątrobowców i glewików Polski. Biodiversity of Poland. Vol. 4. W. Szafer Institute of Botany, Polish Academy of Sciences, Kraków.

Szweykowski J., Buczkowska K. (1996): Liverworts of the Bieszczady Zachodnie Range (Polish Eastern Carpathians) - a vanishing relict boreal flora. Fragmenta Floristica et Geobotanica 41(2): 865-934.

Szweykowski J., Koźlicka M. (1974): H. 245. Cololejeunea calcarea (Libert) Schiffner. In: J. Szweykowski, T. Wojterski (eds). Atlas rozmieszczenia roślin zarodnikowych w Polsce. Seria IV. Wątrobowce (Hepaticae). 8. Polska Akademia Nauk, Komitet Botaniczny i Instytut Botaniki, Warszawa-Poznań: 23.

SZWEYKOWSKI J., KoźlickA M. (1980): H. 44. Riccardia latifrons Lindberg. In: J. Szweykowski, T. Wojterski (eds). Atlas of geographical distribution of spore plants in Poland. Ser. 4. Liverworts (Hepaticae). Part 10. Państwowe Wydawnictwo Naukowe, Warszawa-Poznań: 5-8.

SzYsZYŁowicz I. (1885): O rozmieszczeniu wątrobowców w Tatrach. Sprawozdanie Komisyi Fizyjograficznej 19: 4-125.

TYszKowsKi M. (1993). Eleocharitetum quinqueflorae Lüdi 1921 - the initial plant association of calcareous fens in Poland. Fragmenta Floristica Geobotanica 38(2): 621-626.

Wierzcholska S., Plášek V. (2006): The Bialskie Mts (Eastern Sudetes, Poland), an extraordinary bryological area. Biodiversity Research and Conservation 3-4: 369-372.

Wierzcholska S., Plášek V., Krzysztofiak A. (2010): Mszaki Bryophyta. In: L. Krzysztofiak (ed.). Śluzowce Myxomycetes, grzyby Fungi i mszaki Bryophyta Wigierskiego Parku Narodowego. 
Stowarzyszenie „Człowiek i Przyroda”, Suwałki: 229-298.

Wolejko L., Stańko R., Pawlikowski P., Jarzombrowski F., Kiaszewicz K., Chapiński P., Bregin M., Kozub Ł., Krajewski Ł., Szczepański M. (2012): Krajowy program ochrony torfowisk alkalicznych (7230). Wydawnictwo Klubu Przyrodników, Świebodzin.

Żarnowiec J., Stebel A., Ochyra R. (2004): Threaten moss species in the Polish Carpathians in the light of a new red-list of mosses in Poland. In: A.
Stebel, R. Ochyra (eds). Bryological studies in the Western Carpathians. Sorus, Poznań: 9-28.

For citation: GóRski P., PAwlikowski P., VončINa G., Staniaszek-Kik M., Fojcik B., Rusińska A., Rosadziński S., Wierzgoń M., Szlagowski S. (2019): New distributional data on bryophytes of Poland and Slovakia, 17. Steciana 23, 1: 19-29. doi: 10.12657/ steciana.023.002 